\title{
Evaluating the performance of light traps for sampling small fish and squid in open waters of the central Great Barrier Reef lagoon*
}

\author{
S. R. Thorrold ** \\ Australian Institute of Marine Science, PMB No. 3, Townsville M.C., Townsville, Queensland 4810, Australia \\ and \\ Department of Marine Biology, James Cook University, Townsville, Queensland 4811, Australia
}

\begin{abstract}
Light traps were used to sample small fish and squid from open waters in the central Great Barrier Reef lagoon. A total of 7203 fish, representing some 38 families, and 706 lologinid squid were caught during sampling periods October to January, 1988 to 1990. The fish catch was dominated by the family Pomacentridae (63\% of fish collected), with lower numbers of lethrinids $(6.7 \%)$, clupeids $(6.3 \%)$, mullids $(3.8 \%)$, and scombrids $(2.7 \%)$. Size-frequencies of the fish collected indicated that the light traps sampled late-stage larvae and pelagic juveniles exclusively. No effect of time of night on catch rate was detected. Light traps that were allowed to drift with prevailing water currents caught more fish than anchored traps; this unexpected result may be a function of the effect of current velocity on trap efficiency. Analysis of standard error/sample size curves suggested that optimum replication was achieved with 5 to 6 traps, but that reasonable precision could be obtained with 2 to 3 traps. Coefficients of variation among replicate traps were taxon-specific, ranging from 0.9 (for clupeids) to $0.2-0.1$ (for pomacentrids). These values compare favourably with those obtained from trawl nets. Light traps have considerable potential for sampling nekton that are capable of avoiding conventional towed nets.
\end{abstract}

\section{INTRODUCTION}

Ichthyoplankton surveys have traditionally targeted the early larval stages of marine fishes. This emphasis has been due, at least in part, to a predilection with the 'critical period' paradigm, attributed originally to Hjort (1914). Hjort's hypotheses generated a number of studies that attempted to associate survival during some 'critical period' in early larval life with interannual variability in recruitment (e.g. Lasker 1975, 1981, Sinclair et al. 1985). Increasingly, however, attention has been focussed on the larger larval and pelagic juvenile stages (e.g. Methot 1986, Munk 1988, Suthers \& Frank 1989, Potter et al. 1990). This has been due

- Contribution No. 619 of the Australian Institute of Marine Science

- Present address: Caribbean Marine Research Center, c/o Department of Biological Sciences, Florida Tech, 150 W. University Blvd., Melbourne, Florida 32901, USA largely to the failure of larval abundance estimates from ichthyoplankton surveys to correlate with subsequent year-class strength (Peterman et al. 1988). Fisheries managers have also suggested that direct monitoring of pre-recruits may be a more costeffective management tool than conventional surveys of eggs and larvae (Walters \& Collie 1988).

This shift in focus has highlighted the inability of conventional plankton nets to sample larger, nektonic individuals adequately. Active avoidance of nets by larvae and juveniles is now well documented (e.g. Murphy \& Clutter 1972, Smith \& Richardson 1977 , Clarke 1983, Brander \& Thompson 1989, Heath \& Dunn 1990, and others). Avoidance problems are compounded by a tendency for individuals to become rarer, and more patchily distributed, with increasing size (Hewitt \& Methot 1982). Greater volumes of water must therefore be sampled to provide abundance estimates with adequate precision to test relevant hypotheses. The response to both avoidance and rarity 
of numbers has been to build (increasingly) larger nets, designed to be towed at greater speed. Such a strategy is not, however, without difficulties. Increasing the mouth size and towing speed of a net will also increase the distance at which the net will be detected by both visual and pressure cues (Smith \& Richardson 1977). Clarke (1983) suggested that very soon after anchovies reached sizes capable of avoiding slow, small plankton nets, they were able to avoid any conventional plankton sampler. Despite these caveats, the search for equipment to adequately sample juvenile stages continues to concentrate on towed net designs (Methot 1986, Munk 1988, Potter et al. 1990).

Research on coral reef fishes has recently devoted attention to the sampling of late-larval and pelagic juvenile stages (Doherty 1987a, Milicich 1988, Thorrold \& Milicich 1990). Conventional plankton tows have provided broad-scale descriptions of larval abundances (Milward \& Hartwick 1986, Leis \& Goldman 1987, Williams et al. 1988). Taxonomic and logistic constraints have meant, however, that these studies have revealed little about the recruitment dynamics of coral reef fish populations. Surveys of recently settled fishes have emphasised the extremely episodic nature of replenishment events (reviewed by Doherty \& Williams 1988), and have led to speculation that the larvae of some coral reef fishes may be distributed in large, multi-specific 'patches' (Victor 1984. Williams 1986, Doherty 1987b). Direct verification of such patches has, however, yet to be achieved (Williams \& English 1992). This has been due to both the ephemeral nature of the hypothesised patches, and difficulties sampling the pelagic juvenile stages of many reef species (Choat et al. in press).

Consideration of these problems led Doherty (1987a) to develop an automated light trap to collect reef fish larvae and pelagic juveniles immediately before they settled onto the reef. Preliminary results (Doherty 1987 a, Milicich 1988, Thorrold in press) have suggested that the traps may have general utility for sampling larvae and juveniles from a wide range of taxa. Before light traps can be used quantitatively, however, several potential biases have to be considered. What species, and what sizes, will be sampled by the traps? What systematic biases may be introduced due to behavioural changes during a night? What is the optimum method of deployment? What level of precision can be achieved with realistic replicability? This study addresses these questions from data collected in open waters of the central Great Barrier Reef lagoon.

\section{METHODS AND MATERIALS}

Field work was conducted in coastal waters of the central Great Barrier Reef (hereafter GBR), over 3 yr (1988 to 1990). Systematic sampling across 2 crossshelf transects was conducted in October to December 1988 and October 1989 to January 1990. This coincided with peak spawning activities of most of the fish species in the area (Milward \& Hartwick 1986). During the first summer 4 stations, approximately $8 \mathrm{~km}$ apart, were occupied on each transect (Fig. 1). In the second summer the distance between stations was increased to $16 \mathrm{~km}$, to allow the transects to span the width of the GBR lagoon. Six light traps were deployed at each station, 200 to $300 \mathrm{~m}$ apart and approximately $1 \mathrm{~m}$ below the sea surface. The traps were allowed to fish for $1 \mathrm{~h}$

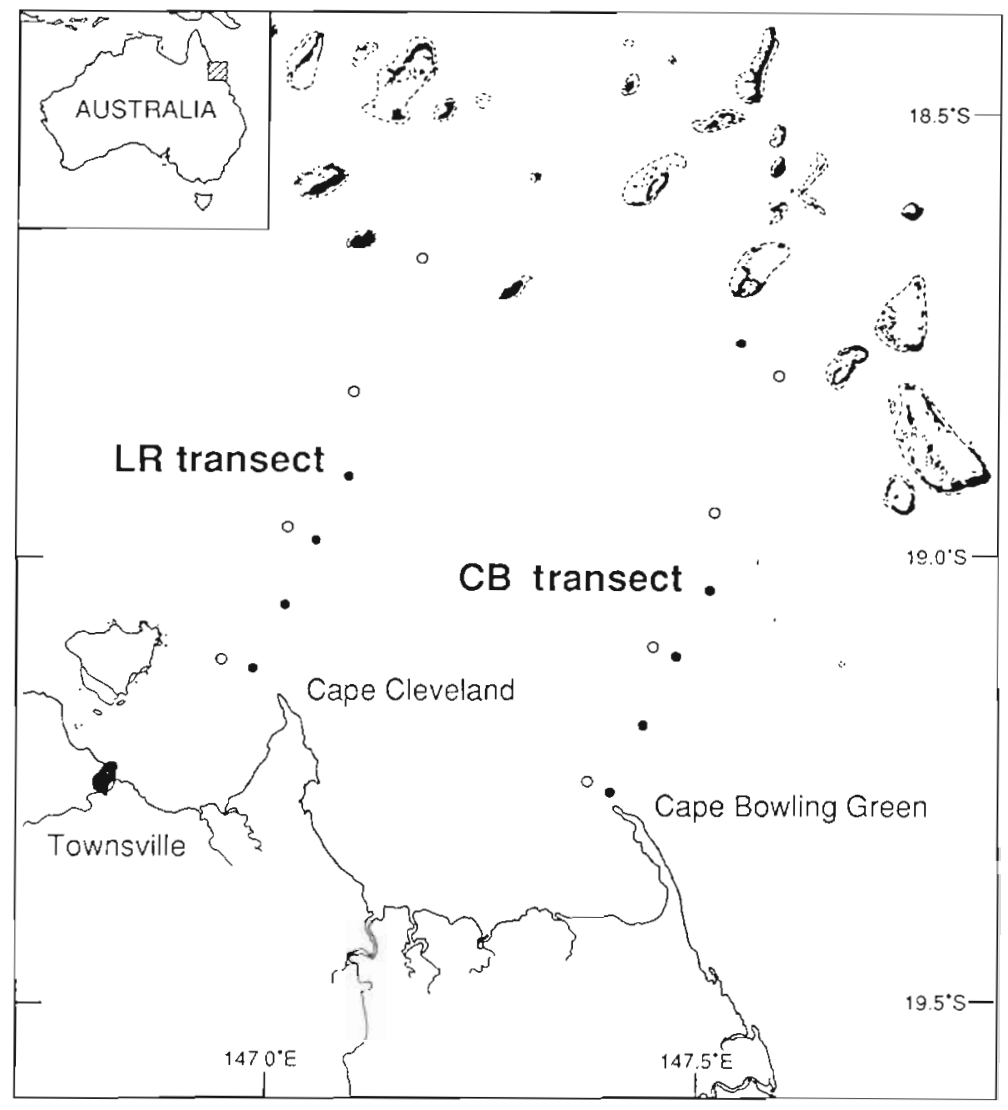

Fig. 1. Locality of LR and CB transects and sampling stations in 1988 (closed circles) and 1989 (open circles) 
before being emptied and redeployed at the next locality. Fishing period was determined by the use of an electronic timer, which operated each trap for $1 \mathrm{~h}$ before automatically switching off the lights in the trap. One transect could be completed in a single night of sampling and each transect was sampled at least once, and up to 3 times, in any given month, depending upon sea conditions. All sampling was conducted within a $10 \mathrm{~d}$ period around the new moon.

The light traps used were similar in operation to those used by Doherty (1987a), and are described in Thorrold (in press). All fish taken during these collections were immediately preserved in 80 to $90 \%$ ethanol for subsequent identification. The traps were always collected within ${ }^{1}{ }_{2} \mathrm{~h}$ of the lights being switched off, to minimise both predation in the trap by piscivorous fishes and escapement. Identification of fish was taken to the lowest possible taxon, following Leis \& Rennis (1983) and Leis \& Trnski (1989). Identification was always to possible to family level, often to generic level, and occasionally individual species were able to be recognised. All fish were also measured under a stereo dissecting microscope with an ocular micrometer. Measurement was made to the nearest micrometer unit $(0.135 \mathrm{~mm}$ at $10 \times$ magnification).

Efficiencies of drifting traps were compared with those of anchored traps on several occasions during the sampling program. On each occasion, 6 traps were set in a line perpendicular to the prevailing current direction. Alternating traps were then either anchored to the bottom, or allowed to drift with the water mass. The traps were then fished for $1 \mathrm{~h}$. Total numbers of fish captured by the different deployment methods were then compared.

The effect of time of night on catch rate was examined over 4 nights at the $16 \mathrm{~km}$ station on the LR transect, during October and November 1990. Four traps were fished within the same general vicinity for $1 \mathrm{~h}$ at 3 times during the night, corresponding to the beginning, middle and end of a normal night's sampling (19:30 to $20: 30 \mathrm{~h}, 23: 30$ to $00: 30 \mathrm{~h}, 03: 30$ to $04: 30 \mathrm{~h})$. A grand mean for each time period, across all nights, was calculated, and $95 \%$ confidence intervals were then bootstrapped (with 1000 iterations; Efron \& Gong 1983) to compare differences in catch rates with time of night. This analysis allowed a direct test of the hypothesis being tested, i.e. that there was no consistent effect of time of night on catch numbers. Pooling across nights allowed the most powerful test for time of night effects available by not considering interactive effects between sampling date and time of night. A significant interaction term would only indicate that high catches were obtained at different times of the night on at least one of the sampling occasions. This would suggest that small-scale variation in fish distributions was more important in determining catch rates than time of night effects.

Replicability and precision of the traps were considered by examining data from the LR transect in October 1989. This subset was chosen as it had maximum sampling effort (a total of 48 samples over 3 nights), and accounted for most (>90\%) of the larvae and juveniles captured during the 1989-90 summer. To determine the optimum number of replicate traps, the procedure outlined by Bros \& Cowell (1987) was followed. Data from the $16 \mathrm{~km}$ station on the LR transect over the 3 sampling nights were pooled to produce a total of 18 'replicates'. By subtracting the nightly mean from each sample within that night, a single data set was generated with mean 0 and a common variance. Pooling across treatments is justified if the sample variances are not heterogeneous; this was tested using Cochran's test (Winer 1971). A Monte Carlo procedure was then used to generate a range of samples for each level of replication. Repeated estimates of the standard error were made by randomly drawing samples, without replacement, from the combined data set, for sample sizes ranging from 2 to 17 . The number of draws made by the Monte Carlo procedure was equal to $10 \%$ of the number of all possible combinations, with a minimum of 3 draws (Bros \& Cowell 1987). These data were then used to construct a graph of standard error versus sample size for the total number of fish collected in the light traps per hour, and for a single species group. Pomacentrus spp., that was abundant over all 3 nights. Coefficients of variation (standard deviation/mean) for different sample sizes were also calculated for the 4 most abundant taxa within a station on a single night. In this case, as there were only 6 replicate traps, all possible combinations of each sample size were used to generate estimates of the coefficient of variation associated with each taxon

\section{RESULTS}

A total of 7203 fish and 706 lologinid squid were captured in 2 yr of systematic sampling, from a fishing effort of 194 light-trap-hours in 1988, and 419 lighttrap-hours in 1989. Although some 38 families of fish were collected (Table 1), the catch in both years was dominated by the family Pomacentridae (Fig. 2). Considerable inter-annual variability in the numbers of each taxon collected was also apparent. Lethrinids and mullids were proportionally more abundant in 1989 than 1988. Conversely, lologinid squids were caught in higher numbers in 1988, despite less fishing effort. A number of families were caught infrequently; $11 \mathrm{fami-}$ lies were represented by fewer than 5 individuals 
Table 1 Total number, maximum catch (number light-trap-hour ${ }^{-1}$ ), and size ranges of small fish and squid collected in the light traps from waters of the central Great Barrier Reef lagoon in 1988 and 1989

\begin{tabular}{|c|c|c|c|c|c|c|c|}
\hline Taxon & $\begin{array}{l}\text { Total } \\
\text { catch }\end{array}$ & $\begin{array}{l}\text { Max. } \\
\text { catch }\end{array}$ & $\begin{array}{c}\text { Range } \\
\text { (mm SL) }\end{array}$ & Taxon & $\begin{array}{l}\text { Total } \\
\text { catch }\end{array}$ & $\begin{array}{l}\text { Max. } \\
\text { catch }\end{array}$ & $\begin{array}{c}\text { Range } \\
\text { (mm SL) }\end{array}$ \\
\hline Apogonidae & 61 & 7 & $6.4-13.6$ & Pomacentridae (continued) & & & \\
\hline Atherinidae & 41 & 4 & $17.2-38.1$ & Chrysiptera spp. & 17 & 5 & $8.8-11.3$ \\
\hline Blenniidae & 52 & 6 & $6.8-20.2$ & Dascyllus aruanus & 3 & 1 & $7.0-9.3$ \\
\hline Bregmacerotidae & 2 & 1 & 14.4 & Dischistodus spp. & 114 & 41 & $6.9-10.7$ \\
\hline Carangidae & 31 & 3 & $8.7-30.5$ & Neopomacentrus spp. & 433 & 20 & $6.4-24.6$ \\
\hline Chaetodontidae & 19 & 3 & $6.0-22.6$ & Plectroglyphidodon spp. & 2 & 1 & $7.0-9.6$ \\
\hline Clupeidae & & & & P. lacrymatus & 78 & 3 & $4.8-11.3$ \\
\hline Clupeinae & 451 & 99 & $9.3-55.5$ & Pomacentrus spp. & 3236 & 136 & $7.9-18.0$ \\
\hline Dussumieriinae & 26 & 6 & $29.5-40.5$ & P. coelestis & 197 & 41 & $7.8-17.4$ \\
\hline Dactylopteridae & 80 & 20 & $5.7-15.5$ & Pristotis jerdoni & 15 & 3 & $8.4-12.2$ \\
\hline Diodontidae & 4 & 1 & $11.6-15.0$ & Small pomacentrids & 3 & 1 & $6.0-11.3$ \\
\hline Engraulidae & 73 & 9 & $15.2-39.4$ & Plesiopidae & 3 & 1 & $10.5-10.7$ \\
\hline Fistulariidae & 1 & 1 & 41.9 & Priacanthidae & 21 & 2 & $6.2-14.3$ \\
\hline Gerreidae & 11 & 2 & $11.6-17.5$ & Pseudochromidae & 1 & 1 & 11.9 \\
\hline Gobiidae & 25 & 2 & $6.8-9.6$ & Sphyraenidae & 5 & 1 & $23.1-23.9$ \\
\hline Hemiramphidae & 2 & 1 & $26.4-27.2$ & Scombridae & & & \\
\hline Holocentridae & 7 & 1 & $9.0-27.6$ & Cybiosarda elegans & 2 & 1 & $15.4-16.8$ \\
\hline Labridae & 9 & 2 & $6.2-9.6$ & Euthynnus affinis & 48 & 10 & $8.4-44.4$ \\
\hline Leiognathidae & 3 & 1 & $10.3-19.2$ & Grammatorcynus spp. & 7 & 2 & $10.4-19.7$ \\
\hline Lethrinidae & & & & Rastrelliger spp. & 1 & 1 & 34.7 \\
\hline Lethrinus spp. & 1080 & 246 & $10.3-22.1$ & Scomberomorus spp. & 74 & 10 & $12.0-25.4$ \\
\hline Lologinid squid & 706 & 78 & $4.3-63.4$ & S. semifasciatus & 31 & 4 & $12.0-41.1$ \\
\hline Lutjanidae & & & & Thunnus spp. & 31 & 4 & $10.5-23.8$ \\
\hline Lutjanus sp. & 1 & 1 & 16.9 & Scorpaenidae & 24 & 4 & $7.6-10.2$ \\
\hline Monacanthidae & 20 & 3 & $14.6-35.7$ & Serranidae & & & \\
\hline Mullidae & 274 & 27 & $14.6-34.4$ & Epinephelus spp. & 27 & 8 & $14.3-18.8$ \\
\hline Myctophidae & 1 & 1 & 10.7 & Siganidae & & & \\
\hline Nemipteridae & 1 & 1 & 12.5 & Siganus spp. & 57 & 19 & $14.0-24.0$ \\
\hline Ostraciidae & 2 & 1 & $5.9-10.4$ & Syngnathidae & 14 & 2 & $49.9-55.2$ \\
\hline Pomacentridae & & & & Synodontidae & 8 & 1 & $22.9-33.6$ \\
\hline Abudefduf spp. & 60 & 10 & $10.7-23.1$ & Teraponidae & 27 & 8 & $10.1-42.8$ \\
\hline Chromis weberi & 302 & 62 & $7.8-13.5$ & Tetraodontidae & 20 & 3 & $12.2-33.8$ \\
\hline C. atripectoralis/viridis & 72 & 5 & $6.9-10.9$ & Iripterygiidae & 12 & 4 & $9.9-12.4$ \\
\hline
\end{tabular}

(Table 1). The largest catch of a single taxon taken by a trap in $1 \mathrm{~h}$ was 246 Lethrinus spp., followed by 136 Pomacentrus spp., 99 clupeids and 78 lologinid squids (Table 1).

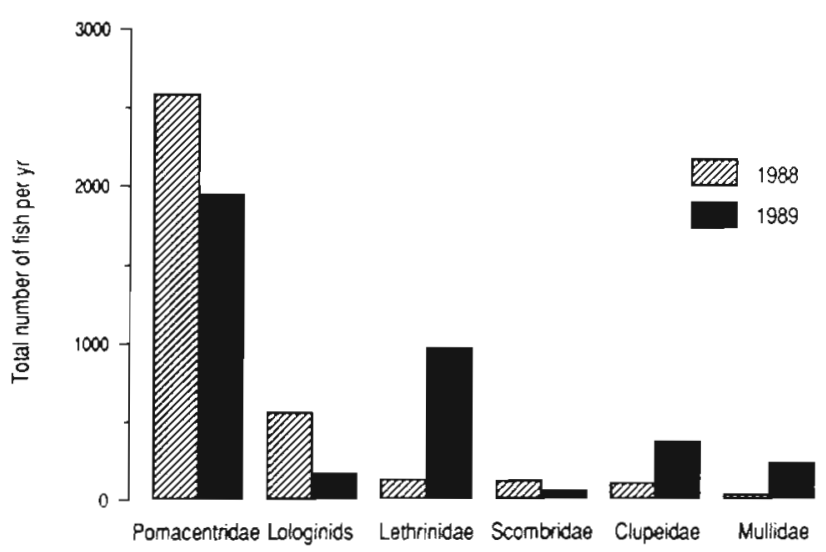

Fig. 2. Total numbers of the 6 most abundant families captured in light traps during 1988 (fishing effort of 194 lighttrap-hours) and 1989 (fishing effort of 419 light-trap-hours)
Size-frequency distributions of the catch indicated that small larvae were not taken in the light traps (Table 1); indeed no preflexion larvae were captured during this study. Size-frequency distributions of the dominant reef-associated taxa suggested size-selection for late-stage larvae and presettlement juveniles (Fig. 3). Sizes from the family Pomacentridae ranged from 4.8 to $24.6 \mathrm{~mm}$ standard length (SL), although $90 \%$ of the fish fell between 10 and $16 \mathrm{~mm} \mathrm{SL}$. Pomacentrus spp. dominated the numbers collected, and showed a reasonably restricted size distribution (from 7.9 to $18.0 \mathrm{~mm} \mathrm{SL}$ : Table 1). Neopomacentrus spp. were collected over a wider size range - from 6.4 to $24.6 \mathrm{~mm}$ SL (Table 1). Lethrinids ranged in size from 10.3 to $28.3 \mathrm{~mm} \mathrm{SL}$ (Fig. 3). Again, over $80 \%$ were concentrated in a narrow size range between 16 and $20 \mathrm{~mm}$ SL. Mullids were collected at sizes from 14.6 to $34.4 \mathrm{~mm}$ SL (Fig. 3). Significant numbers of pelagic juveniles greater than $20 \mathrm{~mm}$ SL were captured, resulting in a size frequency distribution with less kurtosis than either the pomacentrid or lethrinid 


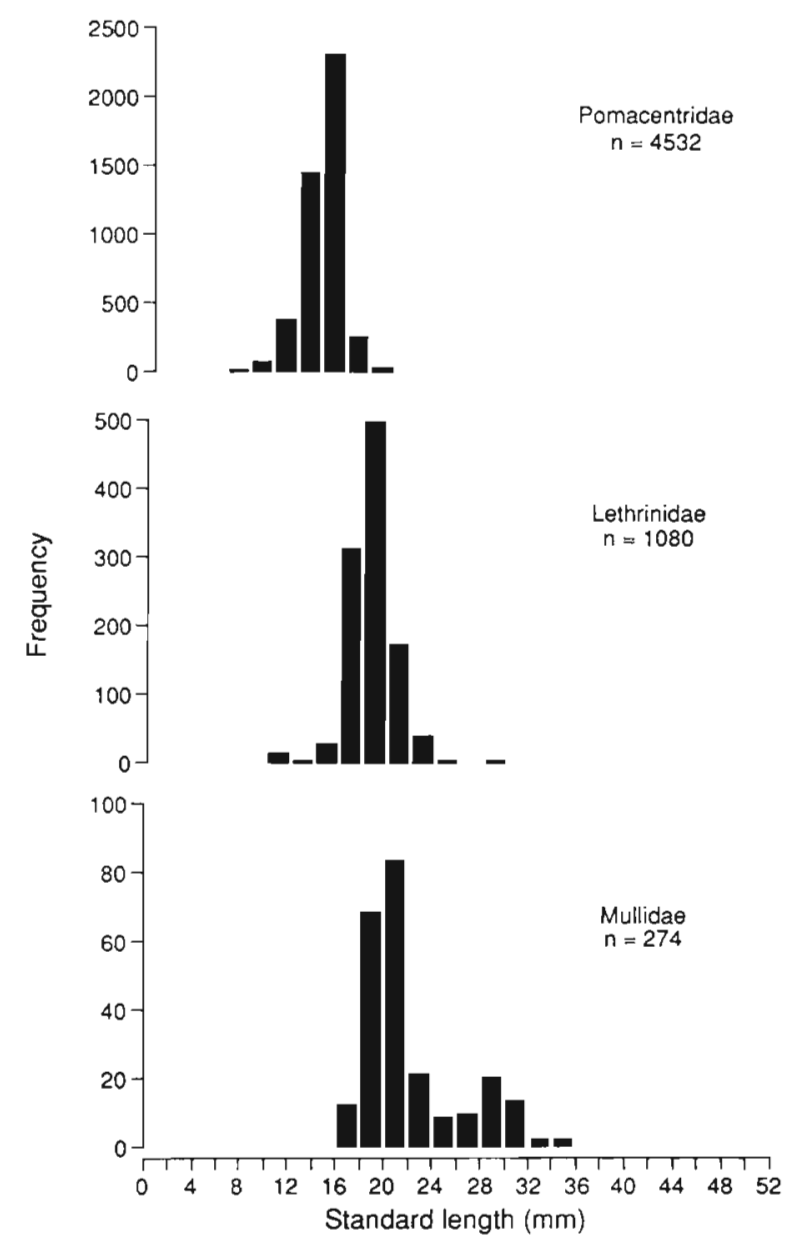

Fig. 3. Size-frequencies of 3 families of coral reef fishes captured in the light traps during 1988 and 1989

distributions. Interestingly, the lower size limit in these families appeared to move up as the mean size increased. Pomacentrids were caught at smaller sizes than either lethrinids or mullids, and also had a smaller average size

Pelagic taxa were captured over much wider size ranges (Fig. 4). Post-larval and juvenile scombrids were taken at sizes ranging from 8.4 to $44.4 \mathrm{~mm}$ SL (Table 1). Lologinid squid were captured over an even greater size range, from 5.5 to $63.4 \mathrm{~mm}$ dorsal mantle length. Clupeids were also captured over a large size range, but a high proportion were between 24 and $30 \mathrm{~mm}$ SL (Fig. 4).

The effect of time of night on catchability was investigated over 4 nights. The mean abundance of fish light-trap-hour ${ }^{-1}$ at each of the 3 sampling times varied from a low of 22 fish light-trap-hour ${ }^{-1}$ during the third and last hour of sampling to a high of 27 fish lighttrap-hour ${ }^{-1}$ during the second hour (Fig. 5). While there is a suggestion of a peak in catchability around midnight, the $95 \%$ confidence intervals of all 3 means overlapped. The null hypothesis of no difference in

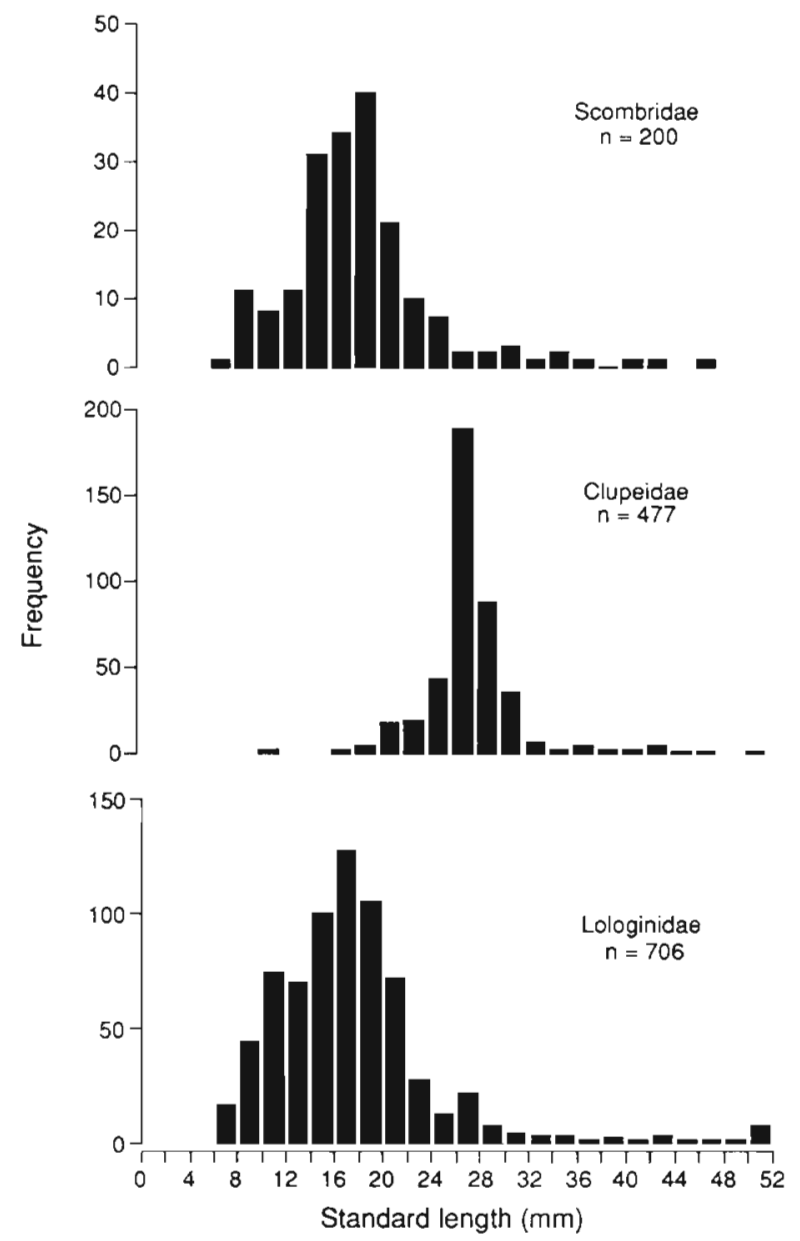

Fig. 4. Size-frequencies of 2 pelagic fish families, and lologinid squids, captured in the light traps during 1988 and 1989

catchability with time of night could therefore not be rejected. The power of this test could not be assessed in a statistically rigorous manner. Ninety-five percent confidence intervals were, however, between 25 and

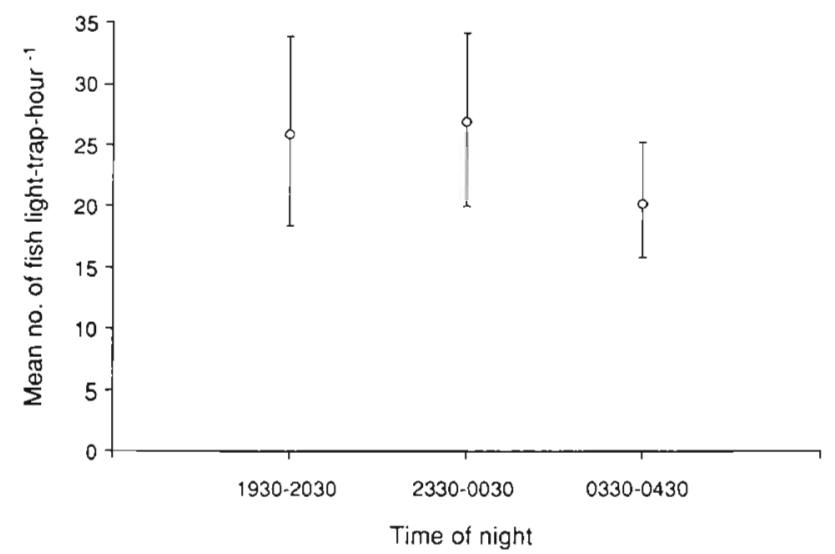

Fig. 5. Mean number of fish light-trap-hour ${ }^{-1}( \pm 95 \%$ confidence intervals) captured in the light traps during 3 time periods of the night 


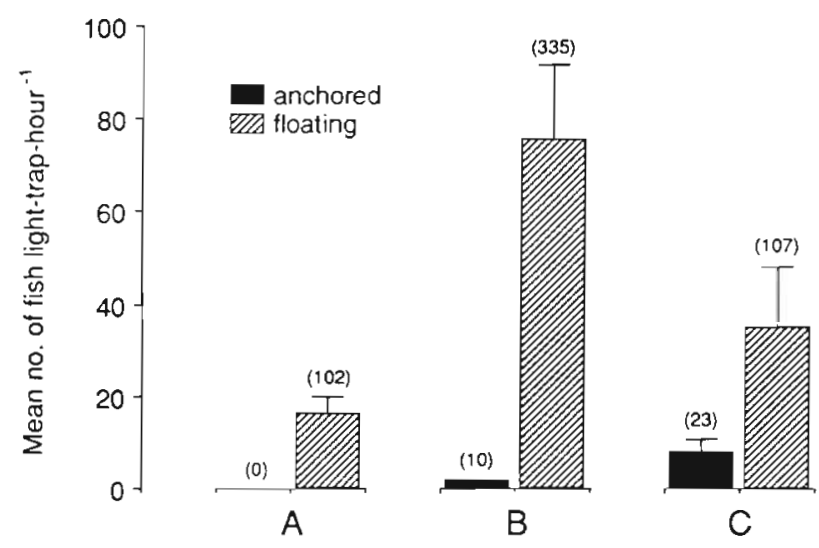

Fig. 6. Comparison of light trap catches (mean number of fish light-trap-hour ${ }^{-1}$; \pm standard error) from drifting and anchored traps fishing in the same body of water. (A) $26 \mathrm{Sep}$ 1989, inshore station on LR transect. (B) 26 Sep 1989, $16 \mathrm{~km}$ station on LR transect. (C) 22 Oct 1990, $16 \mathrm{~km}$ station on LR transect. Numbers above bars refer to total number of fish captured by each method in that set

$30 \%$ of the means for each of the 3 times of night, which suggested that the test did have reasonable power.

Three comparisons of anchored and drifting traps were made. Although several more were attempted, the numbers of fish at these times were too low $1<50$ fish captured in all traps) to make any meaningful comparisons. On all occasions, drifting traps outperformed anchored traps, often by large margins (Fig. 6). This result appeared to be independent of taxa. The first comparison was dominated by clupeids and engraulids, the second by pomacentrids, and the third by pomacentrids and lethrinids.

To estimate the optimum number of replicates, functions of standard error against sample size were generated for both total number of fish captured, and the one taxon abundant enough over all 3 nights to allow statistical analysis, Pomacentrus spp. Total fish numbers were log-transformed to provide homogeneous variances between nights (Cochran's $C=0.648$ after transformation). This was not necessary for the data on Pomacentrus spp. (Cochran's $C=0.53$ ). Both data sets showed similar relationships between standard error and sample size (Fig. 7). If the most conservative standard error estimate is considered, i.e. the largest standard error generated by the Monte Carlo procedure for each sample size, the point of inflexion of the function curve was between 5 and 6 replicates. Alternatively if the average standard error measure is used, a rapid increase in precision occurs between 2 and 3 replicates. Similar conclusions are reached by considering plots of coefficients of variation versus sample size for individual taxa on each night (Fig. 8).

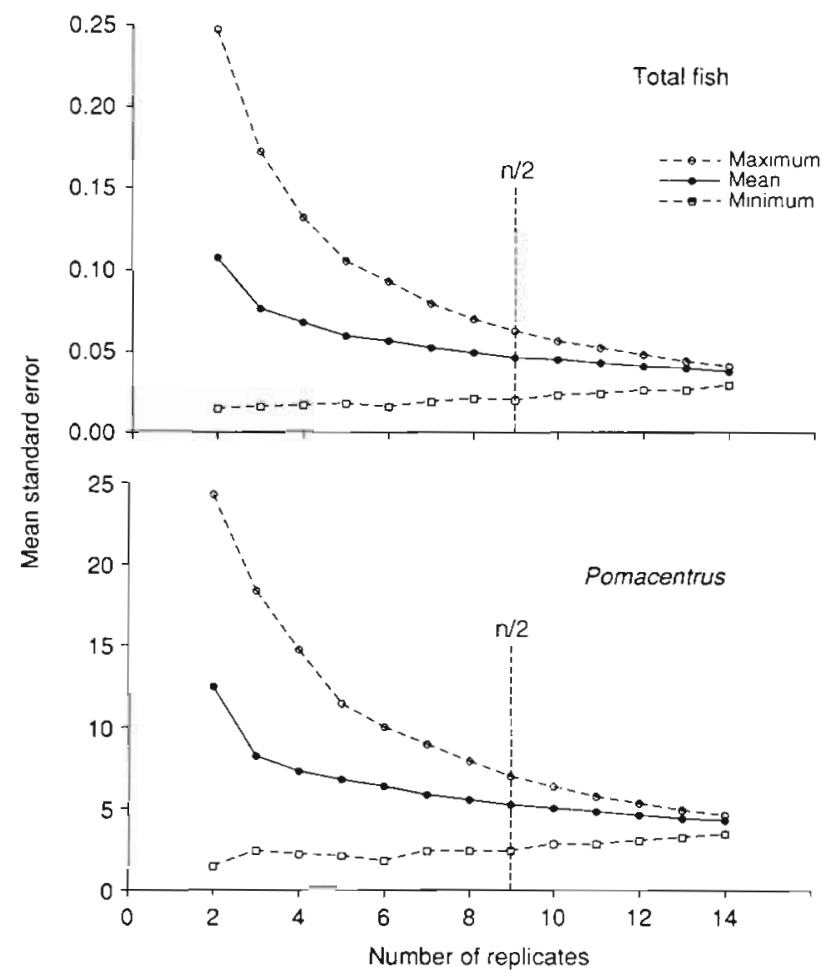

Fig. 7. Relationship between standard error and sample size for light trap samples of total number of fish light-trap-hour ${ }^{-1}$ (top), and numbers of Pomacentrus spp. light-trap-hour ${ }^{-1}$ (bottom). Standard errors for replicates beyond $9(\mathrm{n} / 2)$ are not reliable (Bros \& Cowell 1987)

Coefficients of variation ranged from 0.9 (clupeids) to 0.2 (Pomacentrus spp.) for 2 replicates, through to 0.4 (clupeids) and 0.14 (Pomacentrus spp.) for 6 replicates. Both pomacentrid taxa, Pomacentrus spp. and Chromis weberi, had lower coefficients of variations than either the lethrinids or clupeids.

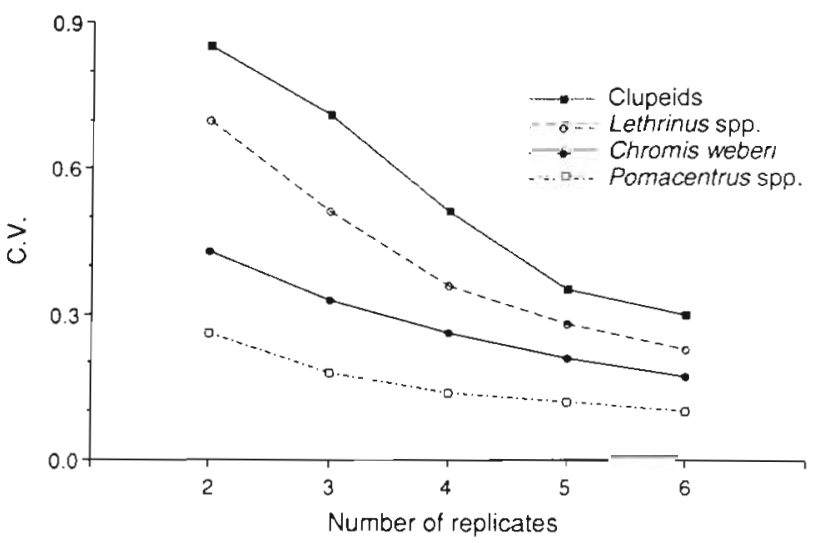

Fig. 8. Relationship between coefficients of variation and sample size for 4 taxa captured in the light traps during October 1989 


\section{DISCUSSION}

The light traps in the present study captured a total of 38 familes. This was considerably more diversity than found around Lizard Island (northern GBR), the only other place the traps have been deployed to date. where Milicich (1988) recorded a total of 24 families. This is not surprising given the greater range of pelagic habitats sampled in this study; traps at Lizard Island were confined to waters immediately adjacent to the reef edge (Doherty 1987a, Milicich 1988). A number of taxa were conspicuously absent or rare in the collections, including pleuronectiform flatfish, platycephalids, apogonids, carangids, gobiids and lutjanids. The larvae of these families represented 6 of the 7 most abundant families caught with a $2 \mathrm{~m}^{2}$ Tucker trawl by Williams et al. (1988), in the only quantitative study of larval fish community structure from this area. It may be assumed, then, that light traps do not effectively sample these taxa, at least when fished in surface waters.

The most striking feature is the similarity of the catches between locations in terms of taxonomic composition. Pomacentrids and lethrinids have dominated 3 years of sampling at Lizard Island (Milicich 1992), and were also the most abundant taxa in this study. Both families appear particularly susceptible to light traps. This may be due to the vertical distributions of these taxa as the larvae of both families are concentrated in the upper water column at night (Leis 1991). However, mullids are also very abundant in the neuston, and, although captured in light traps, they were not nearly as common as pomacentrids and lethrinids. This implies that there may be taxonspecific behaviours determining vulnerability to capture, or alternatively that pomacentrids and lethrinids may be distributed on spatial scales that increase the chance of large, albeit infrequent, catches in light traps. More site-intensive studies will be required to resolve these alternatives.

The absence of any detectable effect of time of night on catchability suggests that records can be compared from traps fished in different localities at different times during the night, at least over the new moon period. Further, in this study, unlike previous ones (Doherty 1987a, Milicich 1988), the light traps were allowed to drift with the water mass, rather than being anchored to the bottom. Although this had the potential disadvantage of reducing the effective volume of water sampled, it reduced the possibility of differential water flow confounding differences in abundances between traps. The result that drifting traps actually outperformed anchored traps was unexpected and indeed counter-intuitive. Anchored traps are presumably exposed to more water than drifting traps. It is possible that at higher current speeds, fish find it harder to swim to, and enter, the traps. During the comparisons, the drifting traps moved between 0.8 and $1.25 \mathrm{~km}$ in the hour of fishing, which suggested that a relatively strong current was flowing at the time. Clearly more detailed work is required to determine the relationship between current speed and trap efficiency.

Drifting traps were used to avoid the problem of differential current flows confounding differences in catch rates among times and localities. It is possible to construct scenarios where this may not be the case. One reviewer of this manuscript noted that if there is a difference in current velocity between surface water containing the trap and deeper water, then although the water surrounding the trap may be 'still', fish may be moving up from the deeper strata into the surface water and then into the trap. This may need to be considered if the traps are fished in very active hydrographic regimes, where there is considerable vertical current shear.

Size-frequency analysis confirmed data from other studies (Choat et al. in press, Thorrold in press) that small larvae are under-sampled by the light traps. The light traps do, however, catch large numbers of larger larvae and pelagic juveniles that are captured only rarely in plankton tows. For example, the light traps have provided unique collections of scombrid larvae and juveniles from this area (Thorrold in press). Similarly, numbers and size-frequencies of lologinid squid compared favourably with large-scale surveys using trawl nets and bongo nets (Rowell et al. 1985). Light traps have also been used extensively in freshwater habitats (Faber 1981, Gregory \& Powles 1985). Gregory \& Powles (1988) compared light traps with a high speed plankton net, and found that the light traps provided more representative size-frequency distributions of larval fishes than the net. In contrast to the present study, they found that the light traps sampled smaller larvae more successfully than the plankton net. This descrepancy may be due to differences in trap design, as the trap used by both Faber (1981) and Gregory \& Powles $(1985,1988)$ was a small, 1-chamber design compared to the larger, 3-chambered trap used here. Alternatively, there may be a qualitative difference in the responses by larval fishes to light in the 2 systems.

The ability of the light traps to collected substantial numbers of (presumably rare) larger larvae and pelagic juveniles may be explained by the considerable volume of water sampled by the traps. Choat et al. (in press) calculated that stationary light traps might be exposed to between 20000 and $200000 \mathrm{~m}^{3}$ of water in an hour at moderate current speeds. On this basis, they argued that the greater catch by light traps compared to bongo and Tucker trawl estimates could be recon- 
ciled simply by the greater volume of water sampled by the aggregation device. However, this was assuming a current speed of between 0.15 and $0.35 \mathrm{~m} \mathrm{~s}^{-1}$. In the present study with drifting light traps, this explanation cannot be advanced. While there is some evidence (M. J. Milicich \& S. R. Thorrold unpubl. data) that fish may be seeing the light traps from greater distances than those used by Choat et al. (in press) when estimating the volume of water sampled, the most parsimonious explanation is that many of the fish captured by light traps are capable of avoiding conventional towed nets.

Methot (1986) listed 4 desirable attributes of a juvenile fish sampler: (1) filter a large volume of water; (2) be unobtrusive to reduce avoidance by larger organisms; (3) retain littie plankton; and (4) be easy to handle. By using light attraction, the traps may be fishing large volumes of water, even when drifting with the water. According to the estimates used by Choat et al. (in press), one would have to tow an $85 \mathrm{~cm}$ bongo net $200 \mathrm{~km}$ to sample the same volume as a light trap fishes in a single hour. The light traps have another major advantage in that they are easily and simultaneously replicated. When combined with the large volume of water sampled, this means the light traps can produce precise abundance estimates, which in this study ranged from 0.9 to $0.14(\mathrm{CV})$. This compares favourably with trawl nets. Methot (1986) reported coefficients of variation of 0.6 and 0.75 , for Engraulis mordax larvae of 10 and $15 \mathrm{~mm}$ SL respectively, from his mid-water trawl. Light traps also appear to satisfy the second criterion, and the locomotory abilities of some species may actually enhance capture rather than retard it. They also collect relatively small amounts of plankton (mainly large, motile mysids, euphausids and amphipods) which present few problems when sorting samples, and they do not suffer from clogging problems when fished in waters with large numbers of gelatinous zooplankton. Finally, the traps are easily deployed from a small vessel without booms or hydraulic winches, which means that multi-ship programs are much more feasible.

One source of concern with the light traps is the perception that such techniques are necessarily qualitative - i.e. it is not possible to convert light trap catches to standardized densities. It must be stressed, however, that conventional techniques are biased also, and that these biases will become more pronounced as larvae grow and become more adept at avoiding towed nets. While it is possible to calculate correction factors for plankton nets (Somerton \& Kobayashi 1989), these factors become increasingly unreliable with size of the fish. Leak \& Houde (1987), for instance, used data from Murphy \& Clutter (1972) to calculate size-specific avoidance rates for Bay anchovy. They suggested that at $9 \mathrm{~mm} \mathrm{SL}, 94 \%$ of larvae were able to avoid the plankton net used in their study. The fact that avoidance levels were so high meant that a change in the size-specific avoidance rate from $90 \%$ to $99 \%$ would have altered abundance estimates by an order of magnitude without any change in the actual density of fish. This is entirely possible, given that avoidance is related to physical parameters such as light levels and water clarity (Brander \& Thompson 1989), and biological factors such as the amount of biolumenscence present in the water column (Weibe et al. 1982). Munk (1988) concluded that it was impossible to standardize the Isaacs-Kidd midwater trawl because of these problems. This implies that despite the increasing sophistication of techniques for correcting catches of fish larvae for size-selection (Somerton \& Kobayashi 1989), these are unlikely to be realistic for large larvae and juveniles.

Light traps will, by their very nature, yield biased estimates of the planktonic community. Clearly if a larval or juvenile fish is not photopositive, light traps will not collect them. However, given that the species of interest is collected in the light trap, it may be possible to calculate the volume of water from which a light trap is drawing fish from a knowledge of the light sensitivity of the fish, the light output of the trap, and the optical quality of the water in which the trap is being used (Milicich 1992). The number of fish captured by a light trap in a given time can then be converted to a standardized effort from a quick measure of water clarity. If this can be achieved, then light traps should be given serious consideration in any sampling program where the aim is to quantify the abundances of larval and pelagic juvenile fish.

Acknowledgements. I thank Maria Milicich, Dave Williams and Peter Doherty for many discussions on the ideas presented here, and for critically reviewing an earlier draft of the manuscript. This work was conducted while the author was holder of the Monkman fellowship. Department of Marine Biology, James Cook University; the Australian Institute of Marine Science provided all logistic support. I thank both institutions for their support.

\section{LITERATURE CITED}

Brander, K. Thompson, A. B. (1989). Diel differences in avoidance of three vertical sampling gears by herring larvae. J. Plankton Res. 11:775-784

Bros, W. E., Cowell, B. C. (1987). A technique for optimizing sample size (replication). J exp. mar Biol. Ecol. 114 $63-71$

Choat, J. H., Doherty, P. J., Kerrigan, B., Leis, J. M. (in press). Larvae and pelagic young of coral reef fishes: companson of three towed nets, a purse seine and two light aggregation devices. Fish. Bull. U.S.

Clarke, T A. (1983). Comparison of abundance estimates of small fishes by three towed nets and preliminary results of 
the use of small purse seines as sampling devices. Biol Oceanogr. 2: 311-340

Doherty, P. J. (1987a). Light-traps: selective but useful devices for quantifying the distributions and abundances of larval fishes. Bull. mar. Sci. 41: 423-431

Doherty, P. J (1987b). The replenishment of populations of coral reef fishes, recruitment surveys, and the problems of variability manifest on multiple scales. Bull. mar Sci. 41 . $411-422$

Doherty, P. J., Williams, D. McB. (1988). The replenishment of coral reef fish populations. Oceanogr. mar. Biol. Ann. Rev. 26: $487-551$

Efron, B., Gong, G. (1983). A leisurely look at the boostrap, the jacknife, and cross-validation. Am. Stat. 37:36-48

Faber, D. J. (1981). A light trap to sample littoral and limnetic regions of lakes. Verh. int. Ver. Limnol. 21.744-749

Gregory, R. S., Powles, P. M. (1985). Chronology, distribution, and sizes of larval fish sampled by light traps in macrophytic Chemung Lake. Can. J. Zool. 63: 2569-2577

Gregory, R. S., Powles, P. M. (1988). Relative selectivities of Miller high-speed samplers and light traps for collecting ichthyoplankton. Can. J. Fish. Aquat. Sci. 45: 993-998

Heath, M., Dunn, J. (1990). Avoidance of a midwater frame trawl by herring larvae. J. Cons. int. Explor. Mer 47: $140-147$

Hewitt, R. P., Methot, R. D. Jr (1982). Distribution and mortality of northern anchovy larvae in 1978 and 1979. CalCOFI Rep. 23: 226-245

Hjort, J. (1914). Fluctuations in the great fisheries of northern Europe. Rapp. P.-v. Réun. Cons. int. Explor. Mer 20: 1-13

Lasker, R. (1975). Field criteria for survival of anchovy larvae: the relationship between inshore chlorophyll maximum layers and successful first feeding. Fish. Bull. U.S. 73 : $453-462$

Lasker, R. (1981). Factors contributing to variable recruitment of the northern anchovy (Engraulis mordax) in the California current: contrasting years, 1975 through 1978 Rapp. P.-v. Réun. Cons. int. Explor. Mer 178: 375-388

Leak, J. C., Houde, E. D. (1987). Cohort growth and survival of bay anchovy Anchoa mitchilli larvae in Biscayne Bay, Florida. Mar. Ecol. Prog. Ser. 37: 109-122

Leis, J. M. (1991). Vertical distribution of fish larvae in the Great Barrier Reef lagoon, Australia. Mar. Biol. 109: $157-166$

Leis, J. M., Rennis, D. S. (1983). The larvae of Indo-Pacific coral reef fishes. University of Hawaii Press, Honolulu, and New South Wales University Press, Sydney

Leis, J. M., Goldman, B. (1987). Composition and distribution of larval fish assemblages in the Great Barrier Reef lagoon, near Lizard Island, Australia. Aust. J. mar. freshwat. Res. 38: 211-223

Leis, J. M., Trnski, T. (1989). The larvae of Indo-Pacific shorefishes. New South Wales University Press, Sydney, and University of Hawaii Press, Honolulu

Milicich, M. J. (1988). The distribution and abundance of presettlement fish in the nearshore waters of Lizard Island. In: Choat, J. H. et al. (eds.) Proc. 6th Int. Coral Reef Symp., Vol. 2. Sixth International Coral Reef Symposium Executive Committee, Townsville, p. 785-790

Milicich, M. J. (1992). Light traps: a novel technique for monitoring larval supply and replenishment of coral reef fish populations. Ph.D. dissertation, Griffith University, Brisbane, Australia

Methot, R. D. (1986). Frame trawl for sampling pelagic juvenile fish. CalCOFI Rep. 27: 267-278
Milward, N. E., Hartwick, R. F. (1986). Temporal and spatial distribution of fish larvae across the continental shelf lagoon of the central Great Barrier Reef. In: Uyeno, T., Arai, R., Taniuchi, T., Matsura, K. (eds.) Indo-Pacific fish biology: Proceedings of the Second International Conference on Indo-Pacific Fishes. Ichthyological Society of Japan, Tokyo, p. 748-758

Munk, P. (1988). Catching large herring larvae: gear applicability and larval distribution. J. Cons int. Explor. Mer 45: $97-104$

Murphy, G. I., Clutter, R. I. (1972). Sampling anchovy larvae with a plankton mesh purse seine. Fish. Bull. U.S. 70: $789-798$

Potter, D. C., Lough, R. G., Perry, R. I., Neilson, J. D. (1990). Comparison of the MOCNESS and IYGPT pelagic samplers for the capture of 0-group cod (Gadus morhua) on Georges Bank. J. Cons. int. Explor. Mer 46: 121-128

Rowell, T. W., Trites, R. W., Dawe, E. G. (1985). Distribution of short-finned squid (Illex illecebrosus) larvae and juveniles in relation to the Gulf Stream frontal zone between Florida and Cape Hatteras. NAFO (Northwest Atlantic Fisheries Organisation) Sci. Coun. Studies 9: 77-92

Sinclair, M., Tremblay, M. J., Bernal, P. (1985). El Niño events and variability in a Pacific mackerel (Scomber japonicus) survival index: support for Hjort's second hypothesis. Can. J. Fish. Aquat. Sci. 42: 602-608

Smith, P. E., Richardson, S. L. (1977). Standard techniques for pelagic fish egg and larval surveys. F.A.O. Fish. Tech. Pap. 175

Somerton, D. A., Kobayashi, D. R. (1989). A method for correcting catches of fish larvae for the size selection of plankton nets. Fish. Bull. U.S. 87: 447-455

Suthers, I. M. Frank, K. T. (1989). Inter-annual distribution of larval and pelagic juvenile cod (Gadus morhua) in southwestern Nova Scotia determined with two different gear types. Can. J. Fish. Aquat. Sci. 46: 591-602

Thorrold, S. R. (in press). Post-larval and juvenile scombrids captured in light traps: preliminary results from the central Great Barrier Reef lagoon. Bull. mar. Sci

Thorrold, S. R., Milicich, M. J. (1990). Comparison of larval duration and pre- and post-settlement growth in two species of damselfish, Chromis atripectoralis and Pomacentrus coelestis (Pisces: Pomacentridae), from the Great Barrier Reef. Mar. Biol. 105: 375-384

Victor, B. C. (1984). Coral reef fish larvae: patch size estimation and mixing in the plankton. Limnol. Oceanogr. 29: $1116-1119$

Walters, C. J., Collie, J. S. (1988). Is research on environmental factors useful to fisheries management? Can. J. Fish. Aquat. Sci. 45: 1848-1854

Weibe, P. H., Boyd, S. H., Davis, B. M., Cox, J. L. (1982). Avoidance of towed nets by the euphausid Nematoscelis megalops. Fish. Bull. U.S. 80: 75-91

Williams, D. McB. (1986). Spatial and temporal scales of processes determining recruitment of fishes of the Great Barrier Reef: some preliminary data. Int. Oceanogr. Comm. Rep., Suppl. 44: 229-239

Williams, D. McB., Dixon, P., English, S. (1988), Cross-shelf distribution of copepods and fish larvae across the central Great Barrier Reef. Mar. Biol. 99: 577-589

Williams, D. McB., English, S. (1992). Distribution of fish larvae around a coral reef: direct detection of a meso-scale, multi-specific patch? Cont. Shelf Res. 12: 923-937

Winer, B. (1971). Statistical principles in experimental design, 2nd edn. McGraw-Hill, New York

Manuscript first received: April 22, 1992

Revised version accepted: September 30, 1992
This article was presented by D. Klumpp. Townsville, Australia 